AKRUAL 1 (1) (2009): 14-27 $e$-ISSN: 2502-6380

\title{
AKRUAL
}

Jurnal Akuntansi

http://fe.unesa.ac.id/ojs/index.php/akrl

\section{EFEKTIVITAS PERANAN AUDITOR INTERNAL DALAM MEWUJUDKAN GOOD CORPORATE GOVERNANC PADA PERBANKAN}

\author{
Eni Wuryani \\ Universitas Negeri Surabaya \\ E-mail: eniwuryani_bm@yahoo.com \\ Tjiptohadi \\ Universitas Airlangga \\ E-mail: tjiptohadi_unair@yahoo.co.uk
}

Artikel diterima: 30 Juli 2010

Revisi terahir: 25 September 2010

\begin{abstract}
Build the role of an effective internal auditors can not be separated from the application of good corporate governance in the company overall. The principles of Good Corporate Governance (GCG) such as fairness, independency, transparency, accountability, and responsibility in an effort to improve professionalism and the welfare of shareholders without ignoring stakeholder interest. Each report weaknesses in internal control or risk control effectiveness of the bank should be immediately followed up by the board of commissioners, board of directors, and executive officers related.
\end{abstract}

Keywords: Internal auditor, Good Corporate Governance (GCG)

\section{PENDAHULUAN}

Good Corporate Governance (GCG) merupakan sistem yang mengatur serta mengendalikan perusahaan guna menciptakan nilai tambah (value added) untuk pemegang sahamnya. Ada dua hal penting yang ditekankan dalam konsep Good Corporate Governance (GCG). Pertama adalah hak pemegang saham untuk memperoleh informasi dengan benar, akurat, dan tepat waktu. Kedua, kewajiban perusahaan untuk mengungkapkan (disclosure) semua informasi mengenai kinerja perusahaan, kepemilikan, dan pemegang saham secara akurat, tepat waktu, dan transparan.

Situasi eksternal dan internal perbankan semakin kompleks. Risiko kegiatan usaha perbankan kian beragam yang menuntut praktik tata kelola perbankan yang sehat. Penerapan prinsip Good Corporate Governance (GCG) selain meningkatkan daya saing juga memberikan perlindungan kepada masyarakat. Penerapan Good 
Corporate Governance (GCG) menjadi suatu keniscayaan mengingat sektor perbankan mengelola dana publik, di mana pengendalian sangat diperlukan untuk memperkecil risiko. Risiko dalam usaha atau bisnis perbankan adalah sesuatu yang alamiah dan selalu akan dihadapi oleh bank. Meniadakan sama sekali risiko tersebut kiranya menjadi tidak realitis. Sikap yang proporsional terhadap risiko di satu pihak dan kebutuhan akan likuiditas serta kepercayaan terhadap perbankan di lain pihak dapat terjaga dengan baik.

Beberapa bank telah membentuk auditor internal di antaranya PT. (Persero) Mandiri, Tbk; PT. (Persero) BNI 46, Tbk; Citibank; Lippobank; HSBC; BCA sejalan dengan letter of intent (LOI) yang ditandatangani oleh pemerintah Indonesia dan International Monetary Fund (IMF), yang mencantumkan jadwal perbaikan pengelolaan perusahaan-perusahaan di Indonesia. Komite Nasional Kebijakan Good Corporate Governance (KNKCG) menekankan pentingnya Indonesia menerapkan standar good corporate governance, karena empat prinsip dasar dalam good corporate governance, yaitu fairness, transparency, accountability, dan responsibility, yang diharapkan dapat mendorong meningkatkan kualitas pelaporan keuangan dan menghambat aktivitas rekayasa keuangan yang dilakukan perusahaan.

\section{KAJIAN PUSTAKA Auditor Internal}

Auditor internal akan mendukung terciptanya perusahaan yang governance apabila dalam melaksanakan perannya dapat berjalan secara efektif dalam mencapai tujuan secara accountable. Faktor-faktor yang memengaruhi efektivitas auditor internal (DeZoort et al., 2002: 42), yaitu:

1. Komposisi yang meliputi keahlian, independensi, integritas, dan objektivitas.

2. Otoritas yang meliputi tanggung jawab, influence (pengaruh) [diperoleh dari dewan komisaris, pemerintah, dan Badan Pengawas Pasar Modal].

3. Resources (sumber daya) yang meliputi jumlah anggota yang cukup, kemampuan akses kepada manajemen dan auditor eksternal.

4. Diligence (ketekunan) yang meliputi dorongan/ insentif, motivasi, peseverance (ketekunan).

Agar dapat menjalankan fungsinya dengan efektif, auditor internal memperoleh otoritas dari dewan komisaris, pemerintah, dan badan yang berwenang dalam pengawasan pasar modal. Otoritas diperlukan dalam menjalankan tanggung jawab dan pengaruh auditor internal (DeZoort et al. 2002: 44). Otoritas diperlukan dalam berhubungan dengan pihak lain yang berkaitan dengan tugas; AICPA dalam DeZoort et al. (2002: 44) menyediakan otoritas bagi auditor in-ternal untuk berkomunikasi dengan auditor eksternal berkaitan dengan upaya mendeteksi kecurangan, tindakantindakan ilegal, ketidaksepakatan dengan manajemen dan lain-lain.

Untuk mencapai auditor internal yang efektif, diperlukan jumlah anggota yang cukup untuk membicarakan dan memecahkan masalah yang dihadapi dan akses ke manajemen dan auditor eksternal. Auditor internal akan efektif jika dapat mengakses informasi secara akurat, tepat waktu, dan lengkap dari manajemen atau auditor atas 
perubahan-perubahan dalam kebijakan akuntansi dan auditing, perubahan-perubahan core business perusahaan dan kondisi tata kelola perusahaan saat ini.

Komposisi, otoritas, dan sumber daya merupakan primary input untuk mencapai auditor internal yang efektif, sedangkan ketekunan merupakan faktor yang dibutuhkan dalam proses mencapai efektivitas (DeZoort et al., 2002: 45). Membangun peran auditor internal yang efektif tidak dapat terlepas dari penerapan prinsip Good Corporate Governance secara keseluruhan di dalam suatu perusahaan di mana independensi, transparansi dan disclosure, akuntabilitas dan tanggung jawab, serta sikap adil menjadi prinsip dan landasan organisasi perusahaan.

Bank sebagai perusahaan pengelola aset paling lancar (liquid) berpotensi menimbulkan kecurangan (fraud) cukup tinggi. Pada 2003-2006 terdapat beberapa bank milik pemerintah yang melakukan tindak kecurangan, misal: kasus Bank Negara Indonesia (BNI) senilai Rp 1,7 triliun, di Bank Rakyat Indonesia (BRI) dan Bank Mandiri yang nilainya tidak sespektakuler BNI. Berbagai upaya telah dilakukan pemerintah dalam menangani masalah kecurangan di bank. Pertama, memperbaiki pengendalian internal pada tiap bank agar sistem makin jelas. Kedua, pembersihan dari oknum-oknum yang bobrok mesti dilakukan secara cepat. Ketiga, pemilihan nasabah melalui know your customer menjadi sangat penting.

Prabantara dalam Supriyanto (2006), modus tindak kecurangan yang terjadi di bank antara lain, dana nasabah tidak dicatat sebagai simpanan di bank, tetapi "disimpan" untuk kepentingan oknum yang disertai pembelokan transfer. Kecurangan yang lain dilakukan pejabat bank dalam bentuk laporan keuangan yang dipalsukan sebagai upaya untuk menutupi penyalahgunaan aset bank. Penyimpanganpenyimpangan di perbankan disebabkan faktor integritas pegawai. Upaya peningkatan integritas individu pegawai dapat ditempuh dengan cara membudayakan perilaku integritas menjadi nilai dasar (core value) perusahaan, yaitu pola perilaku integritas dijadikan budaya kerja perusahaan atau yang lebih dikenal dengan istilah budaya korporat. Secara umum, pelaku tindak kecurangan sering dilakukan oleh orang dalam (insider fraud). Hal ini didukung oleh Ernst \& Young dalam Supriyanto (2006), dimana hasil surveinya menyimpulkan bahwa 82 persen responden menyatakan semua kecurangan melibatkan pegawai di dalam perusahaan dan 28 persen melibatkan pihak manajemen.

\section{Ruang Lingkup Auditor Internal Bank di Indonesia}

Sebagai bagian dari sistem pengendalian internal, SKAI harus melaporkan hasil temuannya secara langsung kepada dewan komisaris atau komite audit (apabila ada), direktur utama, dan direktur kepatuhan. SKAI harus melakukan penilaian yang independen mengenai kecukupan dari dan kepatuhan bank terhadap kebijakan dan prosedur yang telah ditetapkan. Praktik mark-up yang berkembang dewasa ini disebabkan kedua belah pihak (bank dan perusahaan) yang apabila bank tidak awas tehadap praktik mark-up, akan menimbulkan kredit macet.

Dalam menetapkan kedudukan, wewenang, tanggung jawab, profesionalisme organisasi dan ruang lingkup tugas SKAI maka bank wajib berpedoman pada 
ketentuan Bank Indonesia yang berlaku tentang direktur kepatuhan (compliance director) dan Standar Pelaksanaan Fungsi Audit Internal. Langkah-langkah perbaikan yang harus dilakukan bank dalam rangka memperbaiki kelemahan pengendalian internal menurut Bank Indonesia (2003), antara lain:

a) Setiap laporan mengenai kelemahan dalam pengendalian internal atau tidak efektifnya pengendalian risiko bank harus segera ditindaklanjuti oleh dewan komisaris, direksi, dan pejabat eksekutif terkait;

b) SKAI harus melakukan kaji ulang atau langkah pemantauan lainnya yang memadai terhadap kelemahan yang terjadi dan segera melaporkan kepada dewan komisaris, komite audit (apabila ada), dan direktur utama dalam hal masih terdapat kelemahan yang belum diperbaiki atau tindakan korektif belum ditindaklanjuti.

\section{Peranan SKAI terhadap Sistem Pengendalian Internal Bank}

Satuan Kerja Audit Intern (SKAI) sebagai auditor internal pada industri perbank-an harus mampu mengevaluasi dan berperan aktif dalam meningkatkan efektivitas sistem pengendalian internal secara berkesinambungan berkaitan dengan pelaksa-naan operasional bank yang berpotensi menimbulkan kerugian dalam pencapaian sasaran yang telah ditetapkan oleh manajemen bank. Di samping itu, bank perlu memberikan perhatian kepada pelaksanaan audit internal yang independen melalui jalur pelaporan yang memadai, dan keahlian auditor internal khususnya praktik dan penerapan penilaian risiko.

Sistem Pengendalian Internal (SPI) yang efektif merupakan komponen penting dalam manajemen bank dan menjadi dasar bagi kegiatan operasional bank yang sehat dan aman. Sistem pengendalian internal yang efektif dapat membantu pengurus bank menjaga aset bank, menjamin tersedianya pelaporan keuangan dan manajerial yang dapat dipercaya, meningkatkan kepatuhan bank terhadap ketentuan dan peraturan perundang-undangan yang berlaku, serta mengurangi risiko terjadinya kerugian, penyimpangan, dan pelanggaran aspek kehati-hatian.

Sistem Pengendalian Internal (SPI) bank yang andal dan efektif menjadi tanggung jawab dari pengurus dan para pejabat bank. Selain itu, pengurus bank juga berkewajiban untuk meningkatkan risk culture yang efektif pada organisasi bank dan memastikan hal tersebut melekat di setiap jenjang organisasi.

Secara garis besar menurut Bank Indonesia (2003) tujuan sistem pengendalian internal pada perbankan mempunyai beberapa tujuan antara lain:

1) Kepatuhan terhadap peraturan dan perundang-undangan yang berlaku (tujuan kepatuhan). Tujuan kepatuhan untuk menjamin bahwa semua kegiatan usaha bank telah dilaksanakan sesuai dengan ketentuan dan peraturan perundang-undangan yang berlaku, baik ketentuan yang dikeluarkan oleh pemerintah, otoritas pengawasan bank maupun kebijakan, ketentuan, dan prosedur internal yang ditetapkan oleh bank.

2) Tersedianya informasi keuangan dan manajemen yang benar, lengkap, dan tepat waktu (tujuan informasi). Tujuan informasi untuk menyediakan laporan yang 
benar, lengkap, tepat waktu, dan relevan yang diperlukan dalam rangka pengambilan keputusan yang tepat dan dapat dipertanggungjawabkan.

3) Efisiensi dan efektivitas dari kegiatan usaha bank (tujuan operasional). Tujuan operasional dimaksudkan untuk meningkatkan efektivitas dan efisiensi dalam menggunakan aset dan sumber daya lainnya dalam rangka melindungi bank dari risiko kerugian.

4) Meningkatkan efektivitas budaya risiko (risk culture) pada organisasi secara menyeluruh (tujuan budaya risiko). Tujuan budaya risiko dimaksudkan untuk mengidentifikasi kelemahan dan menilai penyimpangan secara dini dan menilai kembali kewajaran kebijakan dan prosedur yang ada di bank secara berkesinambungan.

Sistem Pengendalian Internal (GCG) perlu mendapat perhatian bank, mengingat bahwa salah satu faktor penyebab terjadinya kesulitan usaha bank adalah adanya berbagai kelemahan dalam pelaksanaan SPI bank. Menurut Bank Indonesia (2003) kelemahan dalam pelaksanaan sistem internal bank antara lain:

a. Kurangnya mekanisme pengawasan, tidak jelasnya akuntabilitas dari pengurus bank dan kegagalan dalam mengembangkan budaya pengendalian internal pada seluruh jenjang organisasi;

b. Kurang memadainya pelaksanaan identifikasi dan penilaian atas risiko dari kegiatan operasional bank;

c. Tidak ada atau gagalnya suatu pengendalian pokok terhadap kegiatan operasional bank, seperti pemisahan fungsi, otorisasi, verifikasi, dan kaji ulang atas risk exposure dan kinerja bank;

d. Kurangnya komunikasi dan informasi antarjenjang dalam organisasi bank, khususnya informasi di tingkat pengambil keputusan tentang penurunan kualitas risk exposure dan penerapan tindakan perbaikan;

e. Kurang memadai atau kurang efektifnya program audit internal dan kegiatan pemantauan lainnya;

f. Kurangnya komitmen manajemen bank untuk melakukan proses pengendalian internal dan menerapkan sanksi yang tegas terhadap pelanggaran ketentuan yang berlaku, kebijakan, dan prosedur yang telah ditetapkan bank.

Bank harus melakukan pemantauan secara terus-menerus terhadap efektivitas keseluruhan pelaksanaan pengendalian internal. Pemantauan terhadap risiko utama bank harus diprioritaskan dan berfungsi sebagai bagian dari kegiatan bank sehari-hari termasuk evaluasi secara berkala, baik oleh satuan-satuan kerja operasional maupun oleh Satuan Kerja Audit Internal (SKAI).

Bank Indonesia (2003) pengendalian internal bank terdiri dari lima elemen utama yang satu sama lain saling berkaitan, yaitu pengawasan oleh manajemen dan kultur pengendalian (management oversight and control culture), identifikasi dan penilaian risiko (risk recognition and assessment), kegiatan pengendalian dan pemisahan fungsi (control activities and segregation of duties), sistem akuntansi, informasi dan komunikasi (accountancy, information and communication), serta 
kegiatan pemantauan dan tindakan koreksi penyimpangan/ kelemahan (monitoring activities and correcting deficiencies).

Penilaian risiko merupakan suatu serangkaian tindakan yang dilaksanakan oleh direksi dalam rangka identifikasi, analisis, dan penilaian risiko yang dihadapi bank untuk mencapai sasaran usaha yang ditetapkan. Sistem Pengendalian Internal (SPI) yang efektif mengharuskan bank secara terus-menerus mengidentifikasi dan menilai risiko yang dapat memengaruhi pencapaian sasaran. Penilaian risiko harus pula dilakukan oleh auditor internal sehingga cakupan audit yang dilakukan lebih luas dan menyeluruh.

Penilaian ini harus dapat mengidentifikasi jenis risiko yang dihadapi bank, penetapan limit risiko, dan teknik pengendalian risiko tersebut. Metodologi penilaian risiko harus menjadi tolok ukur untuk membuat profil risiko dalam bentuk dokumentasi data, yang bisa diperbarui secara periodik. Penilaian risiko juga meliputi penilaian terhadap risiko yang dapat diukur (kuantitatif) dan tidak dapat diukur (kualitatif) maupun terhadap risiko yang dapat dikendalikan dan tidak dapat dikendalikan, dengan memerhatikan biaya dan manfaatnya. Selanjutnya bank harus memutuskan untuk mengambil risiko tersebut atau tidak dengan cara mengurangi kegiatan usaha tertentu.

Penilaian tersebut harus mencakup semua risiko yang dihadapi, baik oleh risiko individual maupun secara keseluruhan (aggregate), yang meliputi risiko kredit, risiko pasar, risiko likuiditas, risiko operasional, risiko hukum, risiko reputasi, risiko strategik, dan risiko kepatuhan. Pengendalian internal perlu dikaji ulang secara tepat dalam hal terdapat risiko yang belum dikendalikan, baik risiko yang sebelumnya sudah ada maupun risiko yang baru muncul. Pelaksanaan kaji ulang tersebut antara lain dengan melakukan evaluasi secara terus-menerus mengenai pengaruh dari setiap perubahan lingkungan dan kondisi serta dampak dari pencapaian target atau efektivitas pengendalian internal dalam kegiatan operasi dan organisasi bank.

Sistem Pengendalian Internal (SPI) yang efektif sekurang-kurangnya menyediakan data/informasi internal yang cukup dan menyeluruh mengenai keuangan, kepatuhan bank terhadap ketentuan dan peraturan yang berlaku, informasi pasar (kondisi eksternal) dan setiap kejadian serta kondisi yang diperlukan dalam rangka pengambilan keputusan yang tepat dan dapat dipertanggungjawabkan.

Bank sekurang-kurangnya mengorganisasikan suatu rencana pemulihan darurat (contingency recovery plan) dan sistem back-up untuk mencegah kegagalan usaha yang berisiko tinggi. Prosedur, proses, dan sistem back-up harus didokumentasikan dan dinilai kembali efektivitasnya secara berkala. Untuk memastikan bahwa seluruh rencana dan proses pemulihan darurat (contingency recovery plan) dan sistem backup telah bekerja secara efektif maka pelaksanaan proses dan sistem tersebut harus didokumentasikan dan diuji secara berkala untuk selanjutnya diambil langkah perbaikan yang diperlukan.

Bank Indonesia (2003) bank harus memerhatikan hal-hal sebagai berikut:

a) Ketersediaan bukti dan dokumen yang memadai dalam rangka mendukung proses jejak audit (audit trail). Proses jejak audit tersebut harus dilaksanakan secara 
efektif dan didokumentasikan untuk memastikan bahwa proses otomasi telah bekerja secara efektif dan akurat. SKAI wajib melakukan penilaian terhadap efektivitas dan akurasi proses jejak audit tersebut ketika melakukan evaluasi pelaksanaan pengendalian internal bank;

b) Pelaksanaan pengendalian terhadap sistem komputer dan pengamanannya (general controls) maupun pengendalian terhadap aplikasi software dan prosedur manual lainnya (application controls);

c) Antisipasi terjadinya risiko gangguan atau kerugian yang disebabkan oleh faktorfaktor yang berada di luar jangkauan pengendalian rutin bank sehingga bank harus menyelenggarakan sistem pemulihan (recovery) dan rencana kontingensi serta pengecekan secara berkala atas kemungkinan terjadinya hal-hal yang sulit diprediksi sebelumnya (disaster and recovery plan);

d) Sistem informasi harus menyediakan data dan informasi yang relevan, akurat, tepat waktu, dapat diakses oleh pihak yang berkepentingan, dan disajikan dalam format yang konsisten;

e) Sebagai bagian dari proses pencatatan atau pembukuan, sistem informasi harus didukung oleh sistem akuntansi yang baik termasuk penetapan prosedur dan jadwal retensi pencatatan transaksi.

Sistem komunikasi harus mampu memberikan informasi kepada seluruh pihak, baik internal maupun eksternal. Sistem Pengendalian Internal bank harus memastikan adanya saluran komunikasi yang efektif agar seluruh pejabat/ pegawai bank sepenuhnya memahami dan mematuhi kebijakan dan prosedur yang berlaku dalam melaksanakan tugas dan tanggung jawabnya. Direksi bank harus menyelenggarakan saluran/jalur komunikasi yang efektif agar informasi yang diperlukan terjangkau oleh pihak yang berkepentingan. Persyaratan ini berlaku untuk setiap informasi, baik mengenai kebijakan dan prosedur yang telah ditetapkan, eksposur risiko, dan transaksi aktual maupun mengenai kinerja operasional bank.

Bank Indonesia (2003) struktur organisasi bank harus memungkinkan adanya arus informasi yang memadai, yaitu informasi ke atas, ke bawah, dan lintas satuan kerja/unit:

a) Informasi ke atas untuk memastikan bahwa dewan komisaris, direksi, dan pejabat eksekutif bank mengetahui risiko dan kinerja operasional bank. Saluran informasi ini harus merespon untuk pelaksanaan langkah-langkah perbaikan dan dapat diketahui oleh jajaran manajemen.

b) Informasi ke bawah untuk memastikan bahwa tujuan, strategi, dan ekspektasi bank serta kebijakan dan prosedur yang berlaku telah dikomunikasikan kepada para manajer di tingkat bawah dan para pelaksana.

c) Informasi lintas satuan kerja/unit untuk memastikan bahwa informasi yang diketahui oleh suatu satuan kerja tertentu dapat disampaikan kepada satuan kerja lain yang terkait, khususnya untuk mencegah benturan kepentingan dalam pengambilan keputusan dan untuk menciptakan koordinasi yang memadai. 
Kegiatan pemantauan dan tindakan koreksi penyimpangan harus dilak-sanakan secara berkesinambungan. Bank harus melakukan pemantauan secara terus-menerus terhadap efektivitas keseluruhan pelaksanaan pengendalian internal. Pemantauan terhadap risiko utama bank harus diprioritaskan dan berfungsi sebagai bagian dari kegiatan bank sehari-hari termasuk evaluasi secara berkala, baik oleh satuan-satuan kerja operasional maupun oleh Satuan Kerja Audit Internal (SKAI). Bank harus memantau dan mengevaluasi kecukupan Sistem Pengendalian Internal (SPI) secara terus-menerus berkaitan dengan adanya per-ubahan kondisi internal dan eksternal serta harus meningkatkan kapasitas sistem pengendalian internal agar efektivitasnya dapat ditingkatkan.

Bank Indonesia (2003) langkah-langkah yang harus dilakukan oleh bank dalam rangka terselenggaranya kegiatan pemantauan yang efektif, sekurang-kurangnya adalah:

a) Memastikan bahwa fungsi pemantauan telah ditetapkan secara jelas dan terstruktur dengan baik dalam organisasi bank.

b) Menetapkan satuan kerja/pegawai yang ditugaskan untuk memantau efektivitas pengendalian internal.

c) Menetapkan frekuensi yang tepat untuk kegiatan pemantauan yang didasarkan pada risiko yang melekat pada bank dan sifat/ frekuensi perubahan yang terjadi dalam kegiatan operasional.

d) Mengintegrasikan sistem pengendalian internal ke dalam kegiatan operasional dan menyediakan laporan rutin seperti jurnal pembukuan, management review, dan laporan mengenai persetujuan atas eksepsi/penyimpangan dari kebijakan dan prosedur yang ditetapkan (justifikasi atas irregularities) yang selanjutnya dilakukan kaji ulang.

e) Melakukan kaji ulang terhadap dokumentasi dan hasil evaluasi dari satuan kerja/ pegawai yang ditugaskan untuk melakukan pemantauan.

f) Menetapkan informasi/ feed back dalam suatu format dan frekuensi yang tepat.

Perusahaan menjadi good corporate governance memerlukan auditor internal yang menjamin pengendalian atas risiko usaha dalam batasan lingkungan budaya yang berlaku di perusahaan sehingga terdapat peningkatan terhadap kepatuhan maupun efisiensi usaha.

\section{Hambatan Auditor Internal}

Dalam pelaksanaan tugasnya anggota auditor internal sudah pasti akan menemui hambatan. Budaya bank dengan suasana kerja yang kondusif mampu membuat anggota SKAI bersikap profesional. Hambatan berupa perasaan tidak nyaman terhadap mantan atasan maupun direksi dapat terjawab melalui budaya bank. Menurut Wulandari dalam Supriyanto (2006), budaya kerja yang dikembangkan dengan baik akan mampu menghasilkan nilai-nilai fundamental organisasi yang baik, seperti menjunjung tinggi kejujuran dan integritas, penghargaan atas disiplin dan kualitas kerja serta pelayanan yang prima, penghormatan atas keterbukaan dan transparansi. 
Hambatan terbesar justru muncul dari dalam diri sendiri yaitu perasaan sebagai orang yang berkuasa memeriksa. Selain itu hambatan krusial lain adalah mengenai kedudukan SKAI yang memang harus merasa tidak nyaman dalam memeriksa direksi, sehingga dapat mengurangi tingkat independensi, objektivitas, maupun keahlian auditor internal.

\section{Good Corporate Governance (GCG)}

Kebutuhan untuk menerapkan prinsip-prinsip GCG juga dirasakan sangat kuat dalam industri perbankan. Prinsip-prinsip dasar Good Corporate Governance (GCG) Surya \& Yustiavandana (2006) seperti fairness (keadilan), independency (kemandirian), transparency (transparansi), accountability (dapat dipertanggungjawabkan), dan responsibility (pertanggungjawaban) sebagai upaya untuk meningkatkan profesionalisme dan kesejahteraan pemegang saham tanpa mengabaikan kepentingan stakeholder.

Fairness merupakan perlindungan terhadap hak seluruh pemegang saham, termasuk pemegang saham minoritas (minority shareholder) untuk memperoleh informasi secara tepat waktu dan teratur, memberikan suara dalam rapat pemegang saham, memilih direksi dan komisaris, dan pembagian laba perusahaan. Selain itu fairness juga menekankan kepada pentingnya perlindungan untuk pemegang saham dari berbagai kecurangan seperti praktik insider trading atau keputusan manajer yang merugikan kepentingan seluruh pemegang saham. Bank harus memerhatikan kepentingan seluruh stakeholder berdasarkan asas kesetaraan dan kewajaran (equal treatment). Namun, bank perlu memberikan kesempatan kepada stakeholders untuk memberikan masukan bagi kepentingan bank serta memiliki akses terhadap informasi sesuai dengan prinsip keterbukaan.

Prinsip independensi, bank harus mampu menghindari terjadinya dominasi yang tidak wajar oleh stakeholders. Pengelola bank tidak boleh terpengaruh oleh kepentingan sepihak. Ia harus bisa menghindari segala bentuk benturan kepentingan (conflict of interest). Transparency merupakan suatu bentuk pengungkapan (disclosure) setiap kebijakan atau aturan yang diterapkan perusahaan, sebab kepercayaan investor dan efisiensi pasar sangat tergantung dari pengungkapan kinerja perusahaan secara adil, akurat, dan tepat waktu. Prinsip keterbukaan atau transparansi, misalnya, bank mesti mengungkapkan informasi secara tepat waktu, memadai, jelas, akurat, dan dapat dibandingkan. Informasi tersebut juga harus mudah diakses stakeholders sesuai dengan haknya.

Accountability didasarkan pada sistem internal checks and balances yang mencakup praktik audit yang sehat dan dicapai melalui pengawasan yang efektif yang didasarkan pada keseimbangan kewenangan antara pemegang saham, komisaris, dan eksekutif. Prinsip akuntabilitas, berarti bank harus menetapkan tanggung jawab yang jelas dari setiap komponen organisasi selaras dengan visi, misi, sasaran usaha, dan strategi perusahaan. Setiap komponen organisasi mempunyai kompetensi sesuai dengan tanggung jawab masing-masing. Mereka harus dapat memahami perannya dalam pelaksanaan GCG. Selain itu, bank harus memastikan ada tidaknya check and 
balance dalam pengelolaan bank dan memiliki ukuran kinerja dari semua jajarannya berdasarkan ukuran yang disepakati secara konsisten sesuai dengan nilai perusahaaan (corporate values), sasaran usaha, dan strategi bank, serta memiliki reward and punishment system.

Responsibility merupakan tanggung jawab perusahaan untuk mematuhi hukum dan perundang-undangan yang berlaku, termasuk ketentuan mengenai lingkungan hidup, perlindungan konsumen, perpajakan, ketenagakerjaan, larangan monopoli dan praktik persaingan yang tidak sehat, kesehatan dan keselamatan kerja, dan peraturan lain yang mengatur kehidupan perusahaan dalam menjalankan aktivitas usahanya. Prinsip tanggung jawab (responsibility), artinya bank harus memegang prinsip prudential banking practices. Prinsip tersebut harus dijalankan sesuai dengan ketentuan yang berlaku agar tetap terjaga kelangsungan usahanya. Bank pun harus mampu bertindak sebagai good corporate citizen (perusahaan yang baik).

Forum for Corporate Governance in Indonesial FCGI (2006), menjelaskan ada beberapa bentuk implementasi GCG, antara lain, sistem pengawasan internal (internal control system), pengelolaan risiko (risk management), dan etika bisnis yang dituangkan dalam pedoman perilaku perusahaan (corporate code of conduct). Dalam sistem pengawasan internal, best practices telah memunculkan paradigma baru berupa pengawasan internal yang sangat berbeda dengan konsep pengawasan tradisional.

Yayasan Pendidikan Internal Audit/ YPIA, (2005), konsep pengawasan tradisional, fokus utama pengawasan internal adalah menemukan kesalahan manajemen sebanyak mungkin karena keberhasilan "pemeriksaan" hanya dilihat dari aspek kuantitas temuan pihak auditor internal. Paradigma baru pengawasan internal mengacu pada dua hal pokok. Pertama, pemeriksaan dan konsultasi (assurance and consulting). Kedua, efektivitas pengelolaan risiko melalui risk-based auditing, kontrol dan governance processes. Dimasukkannya assurance dan consulting, menunjukkan makin meluasnya praktik dalam lingkup pengawasan internal. Konsep assurance services lebih luas daripada istilah "pemeriksaan" sebagaimana konsep pengawasan tradisional. Sedangkan, consulting services merupakan nilai tambah. Tanpa mengurangi makna konsep pengawasan tradisional, auditor internal dapat lebih meningkatkan pelayanannya kepada organisasi secara menyeluruh. Anderson (2003) ada empat isu dalam assurance servise yaitu: tingkatan dari assurance, hubungan antara jenis dan tingkatan assurance, masukan assurance di luar organisasi, dan keadaan assurance dalam investigasi fraud. Consulting services meliputi: paduan kontrak kerja, keseimbangan assurance dan consulting, batas dari tingkat consulting di luar fungsi audit internal yang dijalankan, risk dan reward dalam consulting services.

Yayasan Pengendalian Internal Audit/ YPIA (2003), ukuran keberhasilan auditor internal bukan dari jumlah temuan, melainkan dari ukuran sejauh mana auditor internal dapat membantu rekan sekerjanya mengatasi permasalahan yang timbul. Termasuk dalam hal ini adalah aspek pengelolaan risiko, kontrol dan governance processes yang menunjukkan pelaksanaan Good Corporate Governance 
(GCG) sebagai fungsi kontrol dan pengawasan pada akhirnya akan membantu menangani masalah risiko. Semestinya, praktik Good Corporate Governance (GCG) dapat dijadikan alat untuk mengidentifikasi dan mengantisipasi potensi kerugian yang menimpa perusahaan sebagai akibat praktik suap dan korupsi.

Setiap perusahaan harus mampu menerapkan prinsip Good Corporate Governance (GCG) secara benar, mempunyai tingkat sensitivitas yang tinggi terhadap segala kegiatan usaha yang dijalankannya karena Good Corporate Governance (GCG) merupakan bentuk pengaturan internal dalam bank (self regulation). Bila sebuah bank hendak menerapkan Good Corporate Governance (GCG) langkah pertama dan utama adalah adanya dewan komisaris yang berperan aktif, independen, dan konstruktif. Pada saat ini, dibutuhkan struktur, sistem, dan proses yang memadai agar hal tersebut dapat terwujud. Setidaknya mencakup komposisi, kemampuan dan pengalaman anggota dewan, serta bagaimana proses seleksi, peran, dan penilaian kinerja mereka.

Suhardi (2006) fit and proper test bagi pengurus atau pimpinan bank Peraturan Bank Indonesia No 2/23/PBI/2000 tanggal 6 Nopember 2000, mereka yang telah lolos dalam penilaian fit and proper test dianggap telah mampu untuk melakukan kedalaman analisis dan sikap kehati-hatian. Struktur dewan komisaris di setiap negara berbeda, tapi ada satu semangat yang sama untuk menghindari adanya satu orang individu dalam dewan komisaris yang memiliki kekuasaan mutlak. Salah satunya dengan cara pengimbangan melalui keberadaan komisaris independen. Dengan struktur tersebut, dewan komisaris diharapkan dapat tetap independen terhadap kepentingan suatu kelompok tertentu, terutama terhadap pemegang saham pengendali. Komisaris independen, diharapkan dapat tetap berpegang pada kepentingan

Kombinasi kemampuan dan pengalaman dewan komisaris harus bersifat dinamis sesuai dengan kebutuhan strategis dan kontekstual perusahaan. Dewan komisaris sebaiknya terdiri atas individu-individu dengan beragam pengalaman dan latar belakang. Bila perlu dengan rentang usia yang berbeda-beda, sehingga dapat tercipta suatu tim dengan kombinasi kemampuan dan pengalaman kolektif yang solid. Hal lain harus diperhatikan, perusahaan harus menghindari dewan komisaris yang anggotanya memiliki kemampuan dan pengalaman seragam, sehingga tidak mendorong terjadinya diskusi yang cukup dalam dan luas dalam mengkaji dan mengevaluasi opsi-opsi strategis perusahaan.

Proses seleksi komisaris independen harus seobjektif mungkin. Mereka dipilih berdasarkan proses ketat, formal, dan independen. Mulai dari penentuan profil kompetensi dan pengalaman mereka sampai dengan proses wawancara dan evaluasinya. Di samping itu, anggota direksi, terutama direktur utama, tidak boleh terlibat dalam proses seleksi. Sebaliknya, presiden komisaris perusahaan harus terlibat aktif dalam proses seleksi ini. Komisaris independen tidak boleh memiliki hubungan bisnis dengan perusahaan, kecuali gaji atau fee yang diterimanya dari perusahaan dan bukan mantan direktur atau komisaris perusahaan pada periode sebelumnya. Selain itu, mereka tidak boleh terlalu lama menjabat sebagai komisaris 
independen. Misalnya, maksimum satu periode masa kerja saja. Siapa pun yang akhirnya terpilih sebagai komisaris independen, harus memiliki komitmen dan waktu dalam menjalankan peran mereka. Ini berarti, mereka tidak sekadar hadir dalam rapat dewan komisaris, tetapi juga harus selalu melengkapi diri dengan kajian dan analisis isu-isu yang relevan dengan perusahaan.

Badan Pengawasan Pasar Modal (Bapepam) dan Bursa Efek Jakarta (BEJ) sudah mensyaratkan keberadaan komisaris independen dan komite audit bagi semua perusahaan publik. Keputusan Menteri Badan Usaha Milik Negara (BUMN) Nomor 117/2002 sudah mensyaratkan hal yang sama untuk BUMN. Rujukan-rujukan tentang praktik-praktik terbaik sudah tersedia luas. Misalnya, melalui FCGI untuk rujukan praktik terbaik penerapan manajemen risiko dan komite audit serta melalui Indonesian Society of Independent Commissioners (ISICOM) untuk praktik terbaik fungsi dan peran komisaris independen.

Dalam praktiknya, sebagian perusahaan benar-benar sudah berusaha memenuhi ketentuan tersebut dengan memilih komisaris independen sesuai dengan kriteria dan semangat independensi yang diharapkan. Di lain pihak, masih banyak perusahaan yang sekadar memenuhi kepatuhan minimal. Bahkan, sebagian perusahaan memiliki komisaris independen yang masih dipertanyakan kriteria dan semangat independensinya. Sekarang, kembali kepada diri kita sendiri. Bila memang ingin menjadi bagian dari pelaku bisnis dunia, kita harus mulai menerapkan kaidah-kaidah kelas dunia. Bila memang kita ingin menggunakan kesempatan penerapan Good Corporate Covernance (GCG) ini sebagai lompatan transformasi organisasi perusahaan kita, lakukanlah sesegera mungkin agar tidak tertinggal jauh dari pelaku bisnis global lainnya. Membangun dewan komisaris yang mempunyai reputasi berkelas dunia tidak perlu menunggu sampai peru-sahaan benar-benar berkelas dunia. Sebab, ketulusan dan konsistensi tinggi yang dimiliki perusahaan merupakan modal bagi perusahaan untuk memiliki komisaris berkelas dunia.

\section{SIMPULAN}

Membangun peran auditor internal yang efektif tidak dapat terlepas dari penerapan prinsip Good Corporate Governance (GCG) secara keseluruhan di dalam suatu perusahaan fairness (keadilan), independency (kemandirian), transparency (transparansi), accountability (dapat dipertanggungjawabkan) dan responsibility (pertanggungjawaban) menjadi prinsip dan landasan organisasi perusahaan. Sistem pengendalian internal perlu mendapat perhatian bank, salah satu faktor penyebab terjadinya kesulitan usaha bank adalah adanya berbagai kelemahan dalam pelaksanaan sistem pengendalian internal bank. Untuk terciptanya efektivitas pengendalian internal, anggota SKAI harus memahami lingkup pemeriksaan yang menjadi tanggung jawabnya yaitu sebagai management processes, control processes, dan governance processes. Jumlah anggota SKAI harus mencukupi dalam melayani pemeriksaan unit bisnis yang ada. Tingkat independensi anggota SKAI sangat diperlukan dalam pengendalian internal untuk mengungkap kecurangan yang terjadi pada bank. 
Fokus utama pengawasan internal tidak hanya menemukan kesalahan manajemen sebanyak mungkin, melainkan pemeriksaan dan konsultasi (assurance and consulting) serta efektivitas pengelolaan risiko melalui risk-based auditing, kontrol, dan governance processes. Setiap laporan mengenai kelemahan dalam pengendalian internal atau tidak efektifnya pengendalian risiko bank harus segera ditindaklanjuti oleh dewan komisaris, direksi, dan pejabat eksekutif terkait. Prinsipprinsip dasar Good Corporate Governance (GCG) sebagai upaya untuk meningkatkan profesionalisme dan kesejahteraan pemegang saham tanpa mengabaikan kepentingan stakeholder.

Good Corporate Governance (GCG) merupakan sistem yang mengatur serta mengendalikan perusahaan guna menciptakan nilai tambah (value added) untuk pemegang sahamnya. Ada dua hal penting yang ditekankan dalam konsep Good Corporate Governance (GCG), pertama adalah hak pemegang saham untuk memperoleh informasi dengan benar, akurat, dan tepat waktu serta, kedua, kewajiban perusahaan untuk mengungkapkan (disclosure) semua informasi mengenai kinerja perusahaan, kepemilikan, dan pemegang saham secara akurat, tepat waktu, dan transparan. 


\section{DAFTAR PUSTAKA}

Anderson, Urton, 2003, "Assurance and Cosulting Services", The Institute of Auditor internal Research Foundation, Florida United Stated of America, 2003.

Bank Indonesia, 2003, Pedoman Standar Sistem Pengendalian Intern Bagi Bank Umum, Direktorat Penelitian dan Pengaturan Perbankan, September 2003.

Dezoort, F.T. dan S. Salterio, 2002, The Effects of Corporate Governance Experience and Financial Reporting and Audit Knowledge on Audit Committee Members' Judgments, Auditing: A Journal of Practice \& Theory, 21 (Fall): Forthcoming.

Forum For Corporate Governance In Indonesia (FCGI), 2002. Tata Kelola Perusahaan (Corporate Governance) The Essence of Good Corporate Governance : Konsep dan Implementasi Perusahaan Publik dan Korporasi Indonesia. Yayasan Pendidikan pasar Modal Indonesia \& Synergy Communication. Jakarta.

Kinney, William R, 2003, Auditing Risk Assessment and Risk Management Processes, The Institute of Auditor internals Research Foundation, Florida United Stated of America, 2003.

Keputusan Menteri Badan Usaha Milik Negara (BUMN) Nomor 117/2002, tentang Badan Usaha Milik Negara (BUMN)

Peraturan Bank Indonesia No 2/23/PBI/2000 tanggal 6 Nopember 2000, tentang Profit and Proper Test.

Surya \& Yustiavandana, 2006, Penerapan Good Governance, Mengesampingkan hak - hak Istimewa demi Kelansungan Usaha, Lembaga Kajian Pasar Modal dan keuangan (LKMK) dan Fakultas Hukum Universitas Indonesia

Suhardi, Gunarto, 2006, Risiko Kriminalitasasi, Kredit Perbankan, Universitas Atma Jaya Yogyakarta, 2006.

Supriyanto, Eko, 2006, Budaya Kerja Perbankan, Jalan Lurus Menuju Perbankan, Jakarta: Pustaka LP3ES Indonesia, 2006

Yayasan Pendidikan Internal Audit (YPIA), 2005, Menata Bank dengan Corporate Governance, www. gcg, ypia. co.id 